\title{
Pluralisme Sosial Keagamaan Menuju Karakter Bangsa yang Shalih*
}

\author{
Zahratunnisa Hamdi ${ }^{1}$ \\ Program Pascasarjana Institut PTIQ Jakarta \\ $\underline{10.15408 / \text { sjsbs.v7i12.18292 }}$
}

\begin{abstract}
The questioning argued that the social problems of the community were directed at the 2005 MUI fatwa which prohibits pluralism. MUI is seen as wrongly assessing the addition of the word "ism" as an ideological signification of the root word "plural", considering that the word pluralism in various linguistic and encyclopaedia literatures has more than just a theological meaning, but also a social meaning. However, critics have never provided a solution in the form of a substitute for the MUI version of pluralism. Besides, some of them are trapped in claiming to support the doctrine of equality of truth for all religions which is banned by MUI even though they try to appear objective at first. The method used in this research is qualitative research methods with a normative approach. The results of the research stated that MUI strives to fight for the harmony of Indonesia's pluralistic society through its formulated "plurality" inclusivism in the hope of realizing peace and harmony in a multi-religious nation. This paper also seeks several sides of the pluralism perspective in philosophical, religious and historical literature, and the possibility of applying its sociopolitical meaning in realizing the moral and righteous character of a national society.
\end{abstract}

Keywords: Pluralism, Theology, Social Religion, Diversity

\begin{abstract}
Abstrak
Penyoaalan berdalih persoalan sosial masyarakat diarahkan kepada fatwa MUI tahun 2005 yang mengharamkan faham pluralisme. MUI dipandang salah menilai tambahan kata "isme" sebagai penyifatan ideologis terhadap kata dasar "plural", mengingat kata pluralisme dalam berbagai literatur kebahasaan dan ensiklopedi memiliki arti lebih dari sekedar makna teologis, tetapi juga makna sosial. Akan tetapi, para pengkritik tidak kunjung memberikan solusi berupa kata pengganti bagi pluralisme versi MUI. Di samping, diantara merekapun terjebak untuk menyatakan mendukung doktrin persamaan kebenaran semua agama yang diharamkan MUI meskipun berusaha terlihat objektif di awal. Metode yang digunakan dalam penelitian ini adalah Metode Penelitian Kualitatif dengan pendekatan normatif. Hasil penelitian menyatakan bahwan MUI berupaya memperjuangkan harmoni masyarakat majemuk Indonesia melalui inklusivisme "pluralitas" yang dirumuskannya dengan harapan dapat mewujudkan kedamaian dan kerukunan bangsa yang multi agama. Tulisan ini pun mengupayakan beberapa sisi pandang pluralisme dalam literatur filsafat, agama dan kesejarahan, dan kemungkinan penerapan makna sosial politisnya dalam mewujudkan karakter masyarakat berbangsa yang bermoral dan shalih.

Kata kunci: Pluralisme, Teologis, Sosial Agama, Keberagaman
\end{abstract}

* Received: July 15, 2020, Revision: July 18, 2020, Published: December 5, 2020.

${ }^{1}$ Zahratunnisa Hamdi adalah mahasiswi Program Doktoral di Perguruan Tinggi Ilmu al-Quran (PTIQ) Jakarta. 


\section{A. PENDAHULUAN}

Pada tahun 1971, John Lennon mempopulerkan lagu Imagine yang dinobatkan sebagai lagu ketiga terbaik sepanjang masa versi majalah Rolling Stone tahun 2004. Lagu yang menurut Presiden AS Jimmy Carter diputar sesering lagu kebangsaan di negara-negara dunia itu oleh Lennon sendiri dikomentari sebagai lagu anti agama, anti nasionalistis, anti konvensional dan anti kapitalistis. Lennon juga melukiskannya sebagai Manifesto Komunis ${ }^{2}$. Begitu vulgarnya Lennon menyatakan dan betapa halusnya dia merayu dunia akan idenya melalui bahasa dan musik. Dia berusaha meyakinkan bahwa semua kekerasan fisik dan perampasan hak serta segala kedhaliman yang terjadi merupakan kesalahan akan adanya agama, sistem kenegaraan, dan sistem perekonomian posesif. Rupanya pengaruhnya cenderung berhasil ketika Bandara Liverpool berganti nama dengan namanya dan menggunakan motto dari petikan lagunya: Above us only sky, berpuluh tahun setelah kematiannya di tangan penggemarnya sendiri. Namun pada akhirnya Lennon sendiri setengah mengakui bahwa dia hanya bermimpi sehingga dalam bait liriknya berkata: "you may say $i$ am a dreamer", dan judul lagunya pun hanya sebatas "imagine".

Keresahan yang melatari ide lagu Lennon tersebut memang nyata menjadi permasalahan sosial dimana keadilan terenggut dan kemanusiaan terinjak. Akan tetapi terlalu naif jika agama dituduh sebagai asal permasalahannya dan menginginkan untuk menghapusnya. Agama merupakan fitrah manusia, oleh karenanya tidak mungkin untuk tidak ada. Sebagai sumber moralitas dan kebenaran agama juga tidak mungkin bertentangan dengan nilai-nilai kebenaran universal. Dengan demikian, perdamaian dan keadilan hanya dapat terwujud dengan kembali kepada agama. Luka panjang konflik sejarah yang diwarnai keagamaan sejatinya bukan terjadi atas sebab agama melainkan atas sebab kedhaliman manusia yang justru bertentangan dengan agama itu sendiri. Tidak dipungkiri, kenyataan pahit di masa lampau meninggalkan kesan yang tidak terlupakan dan menimbulkan ketegangan hubungan manusia. Seperti perang salib yang memakan waktu beberapa abad, dan ekspansi bangsabangsa Eropa ke negeri-negeri muslim yang tidak dapat dinafikan bertujuan menjajah, menjarah dan menyiarkan agama Kristen (proselytizing)3, hingga kini masih memberikan efek yang mengganggu bagi hubungan antara kedua umat beragama.

Meniadakan agama juga bukan solusi jika memang perdamaian yang diinginkan. Terbukti dalam sejarah komunisme pun di setiap tempat menyisakan kisah berdarah-darah. Maka nun jauh sebelum Lennon kecewa, Martin Luther pun telah menggugat gereja dan bukan menggugat agama. Yang Luther dan pengikutnya lakukan adalah memperbaharui paham agama mereka berbeda dengan mainstream lama, sehingga mereka dikenal sebagai kaum liberal. Namun pada fase sejarah berikutnya kalangan ini mengembangkan pemikiran-pemikiran yang menyeret pada relativitas kebenaran yang diklaim oleh setiap agama sedari awal. Atas dasar keadilan sosial mereka menelurkan gagasan pluralisme agama yang menyatakan bahwa semua

\footnotetext{
${ }^{2}$ https://id.m.wikipedia.org/wiki/Imagine

${ }^{3}$ Syamsuddin Arif," Interfaith Dialogue" dan Hubungan Antaragama dalam Perspektif Islam", Jurnal Tsaqafah, Vol. 6, No I, April 2010, hal: 158.
} 
agama adalah sama. Hal ini menjadi over dosis karena semestinya untuk menciptakan keadilan sosial diselesaikan dengan pisau sosial dan bukan ideologis.

\section{B. METODE PENELITIAN}

Metode penelitian yang digunakan adalah metode kualitatif berbasis kepustakaan (library research). Pendekatan yang digunakan adalah deskriptif kualitatif yang bertujuan untuk memberi gambaran atau mendeskripsikan kenyataan yang ada atau apa yang terjadi atau kenyataan sebenarnya pada obyek yang diteliti.

\section{HASIL TEMUAN DAN PEMBAHASAN}

\section{Kebhinekaan Yang Dipersoalkan}

Jamak diketahui kekayaan Indonesia akan budaya dan kultur yang multi. Seluruh bangsa ini kiranya sepakat untuk mensyukuri yang mengikrarkannya bersama dalam sebuah sasanti Bhinneka Tunggal Ika yang lekat tertera dalam simbol negara, Garuda Pancasila. Jika dipahami sasanti tersebut mempunyai dua unsur, yakni pertama Bhinneka atau keragaman multi sebagai kekayaan yang nyata, dan kedua adalah Tunggal atau persatuan, kerukunan dan kedamaian dalam keragaman tersebut. Yang pertama merupakan realitas yang harus disyukuri, sedangkan yang kedua adalah tujuan dari keragaman tersebut beserta segala unsurnya yang harus diperjuangkan bersama secara serius. Namun acapkali permasalahan menjadi rancu karena rasio di atas dibalik, sehingga yang diperjuangkan adalah kebhinnekaan untuk menjadi tidak terhingga tanpa mempertimbangkan aspek-aspek yang berkaitan dengan unsur kebhinnekaan yang telah terlebih dahulu ada, sehingga dapat menyinggung dan menyakiti yang lainnya. Seharusnya unsur tunggal-lah yang diperjuangkan agar kebhinnekaan berjalan aman. Sehingga -meminjam istilah Ahmad Syafi'i Ma' arif- persatuan bangsa tidak justru menjadi persatuan bangsa ${ }^{4}$.

Kasus Ahmadiyah misalnya, jika dilihat dari sudut kebhinnekaan saja yang pasti bermain adalah emosi, sehingga otomatis diberikan tempat seluas-luasnya. Akan tetapi kemunculan Ahmadiyah ternyata bersinggungan dengan unsur kebhinnekaan yang telah ada dan mempunyai keterkaitan aspek dengannya yaitu agama Islam. Karena Ahmadiyah mengklaim dirinya sebagai bagian dari agama Islam dengan doktrin yang dinilai menodai ajaran pokok Islam mainstream yaitu adanya nabi setelah Nabi terakhir Muhammad shallallahu 'alaihi wa sallam. Seharusnya dalam kasus seperti ini dikembalikan kepada internal umat Islam untuk diselesaikan atau dicarikan solusi oleh mereka, mengingat hal ini merupakan urusan rumah tangga mereka yang merupakan unsur asli dari kebhinnekaan Indonesia. Seperti misalnya agar Ahmadiyah mendirikan agama Ahmadiyah sendiri dan tidak mengklaim sebagai bagian agama Islam $^{5}$. Cara ini lebih rasional untuk mempertahankan ketunggalan dari kebhinnekaan

4 Ahmad Syafi'i Ma'arif, Menimbang Kembali Keindonesiaan Dalam Kaitannya Dengan Masalah Keadilan, Kemanusiaan, Kebhinnekaan Dan Toleransi, Fiqih Kebhinnekaan, Bandung: Mizan, 2014, hal. 21.

$$
\text { Hasyim Muzadi: Mau Aman, Ahmadiyah Agama Baru, }
$$
https://m.hidayatullah.com/berita/nasional/read/2011/02/23/46652/hasyim-muzadi-mau-aman-ahmadiyahagama-baru.html. Diakses: 20 Maret 2020. 
yang telah ada. Karena tujuan bangsa ini adalah merawat kebhinnekaan agar tetap tunggal bersatu tanpa keretakan. Merawat kebhinnekaan yang telah ada lebih menjamin persatuan, dan melukai salah satu unsurnya berpotensi perpecahan. Peran dan ketegasan pemerintah sangat vital, mengantisipasi agar kebhinnekaan yang tunggal tidak tercemar maka potensi kekerasan harus dicegah, bukan menindaknya setelah pecah. Kualitas kebhinnekaan terdapat pada kecakapan bangsa ini merawatnya, bukan pada kuantitas perbedaan yang tidak terbatas jenis dan warnanya dengan ketegangan antar kelompok yang selalu menghantui. Sedangkan dalam kasus Ambon dan Situbondo, K.H Abdurrahman Wahid selaku kepala negara saat itu mengambil keputusan bijak yaitu melarang pelibatan agama dalam konflik-konflik tersebut, maka dilarangnya pendirian laskar-laskar agama dalam penyelesaiannya. Beliau menegaskan bahwa perjuangan hak asasi manusia demokrasi dan kedaulatan hukum adalah perjuangan universal dan bukan hanya klaim sebuah agama saja ${ }^{6}$. Disini beliau melihat jeli situasi kondisi kemajemukan bangsa ini, sehingga solusi masalah sensitif ini harus diselesaikan dengan alat yang netral, memangkas potensi dendam sosial yang rentan di belakang nanti. Demikian pula seharusnya bangsa ini berpikir selepas beliau pergi, dengan analogi sikap beliau tersebut maka tindakan seperti menjaga gereja di hari natal oleh ormas agama tertentu juga rentan menimbulkan friksi dan mengancam kebhinnekaan bangsa bahkan kebhinnekaan umat Islam Indonesia dan juga kebhinnekaan ahlussunnah wa al jamaah. Selama lembaga pemerintahan masih mempunyai aparat keamanan resmi seharusnya memilih untuk membiarkan semua berjalan netral.

\section{Kontroversi Fatwa MUI}

Beberapa fakta ketegangan yang terjadi dalam negeri selama ini otomatis mendapat perhatian dari kalangan intelektual dan menjadi barometer atas presensi keadilan dari beragam sisi. Salah satu impaknya adalah merebaknya pemikiran pluralisme agama yang ramai menjadi perdebatan teologis yang panas di kalangan muslim Indonesia saat itu, sehingga Majelis Ulama Indonesia (MUI) mengeluarkan fatwa haram atas paham tersebut. Fatwa yang berdasarkan hasil rumusan MUNAS VII MUI tersebut dimaknai sebagai berikut:

"Pluralisme agama adalah suatu paham yang mengajarkan bahwa semua agama adalah sama dan karenanya kebenaran setiap agama adalah relatif. Oleh sebab itu setiap pemeluk agama tidak boleh mengklaim bahwa hanya agamanya saja yang benar sedangkan agama yang lain salah. Pluralisme agama juga mengajarkan bahwa semua pemeluk agama akan masuk dan hidup berdampingan di surga."

Dalam penjelasan tentang hukum pluralisme, MUI menyatakan:

"Dalam masalah aqidah dan ibadah, umat Islam wajib bersikap eksklusif, dalam arti haram mencampuradukkan aqidah dan ibadah umat Islam dengan ibadah pemeluk lain. Bagi masyarakat muslim yang tinggal bersama pemeluk agama lain (pluralitas agama), dalam masalah sosial yang tidak berkaitan dengan aqidah dan ibadah umat

${ }^{6}$ Muhammad Rifai, Gus Dur, Jogjakarta:Ar-Ruzz Media, 2013, hal101-102. 
Islam bersikap inklusif dalam arti tetap melakukan pergaulan sosial dengan pemeluk agama lain sepanjang tidak saling merugikan".

Fatwa MUI ini walaupun mendapatkan respons positif dari banyak kalangan dan dianggap memberi pencerahan dan jawaban atas kegalauan umat tetapi juga mendapatkan kontra dari sebagian kalangan akademisi Islam sendiri. Kritik mereka berkisar pada makna pluralisme, apakah benar sesuai dengan definisi MUI ataukah tidak. Apakah benar penambahan "isme" pada kata plural menjadikannya mutlak bermakna ideologis yang menyeret kepada relatifitas kebenaran agama?

Dari segi linguistik apa yang dijelaskan oleh Hamid Fahmi Zarkasyi nampaknya dapat mewakili, yakni:

"Dari berbagai kamus, pluralisme dapat bermakna dua hal: pertama, pengakuan terhadap kualitas majemuk atau toleransi terhadap kemajemukan. Kedua, doktrin yang berisi: a) pengakuan terhadap kemajemukan prinsip tertinggi, b) pernyataan tidak ada jalan untuk menyatakan kebenaran tunggal atau kebenaran satu-satunya tentang suatu masalah, c) ancaman bahwa tidak ada yang benar, atau semua pendapat itu sama benarnya (no view is true, or that all view are equally true). (lihat, The Golier Webster Int. Dictionary of The English Language; Oxford Dictionary of Philosophy; Oxford Advanced Learners Dictionary of Current English)."

Disimpulkan dari beberapa pengertian ini bahwa pluralisme berkisar pada arti toleransi keberadaan multi prinsip, ketiadaan prinsip kebenaran tunggal, serta sikap skeptik atas kebenaran dari semua prinsip. Lalu apa yang dikatakan John Hick tokoh pluralisme internasional saat ini? Berikut pandangan Hick yang dirangkum Ahmad Muttaqien dalam artikelnya ${ }^{8}$ :

a. Semua agama adalah respons terhadap keberadaan tertinggi yang bersifat transenden yang disebut oleh Hick: The Real.

b. The Real itu melampaui konsep manusia sehingga semua agama tidak sempurna dalam relasinya terhadap The Real tersebut.

c. Oleh karena itu, tentang agama-agama Hick berkata: “agama-agama tidak mungkin semuanya benar secara penuh, mungkin tidak ada yang benar secara penuh, mungkin semua adalah benar secara sebagian".

d. Hick membedakan The Real sebagai realitas umat dan The Real yang ditangkap dan dipersepsikan oleh agama-agama sebagai personae (berpribadi): Allah, Yahweh, Krishna, Syiva atau Impersonae (tidak berpribadi): Tao, Nirguna Brahman, Nirvana, Dharmakaya.

e. Dalam konsep Hick, Personae dan Impersonae adalah penafsiran terhadap The Real. The Real tersebut tidak dapat disebut sebagai Personal atau Impersonal, memiliki tujuan atau tidak memiliki tujuan, baik atau jahat, substansi atau proses, bahkan satu atau banyak. The Real melampaui semua kategori manusiawi seperti itu.

\footnotetext{
${ }^{7}$ Hamid Fahmi Z dalam Ahmad Muttaqien, Rekonstruksi Gagasan Pluralisme Agama, Jurnal AlAdyan/Vol. IX, No. 1/Januari-Juni/2014, hal. 98.

${ }^{8}$ Ahmad Muttaqien, Rekonstruksi Gagasan Pluralisme Agama, Jurnal Al-Adyan, hal. 99.
} 
f. Keselamatan adalah proses perubahan manusia dari berpusat pada diri sendiri (self-centered) menjadi berpusat pada Realitas tertinggi (Real-centered)

g. Kriteria untuk mengetahui apakah seseorang sudah diselamatkan atau tidak adalah kehidupan moral dan spiritualnya yang mencerminkan kekudusan. Diantara kualitas-kualitas itu adalah: belas kasih, kasih kepada semua manusia, kemurnian, kemurahan hati, kedamaian batin dan ketenangan, sukacita yang memancar.

Anis Malik Thoha dalam sebuah wawancara menyebutkan, nama The Real atau Tuhan yang absolut ini diusulkan oleh Hick yang kebetulan ia dapatkan padanan katanya dalam Islam sebagai Al-Haq. Dalam paham pluralisme semua orang harus mengimani tuhannya John Hick ini sehingga pada hakikatnya mereka telah membangun absolutisme sendiri. Karenanya, pluralisme sarat dengan self-inconsistent ${ }^{9}$. Selanjutnya beliau mengatakan bahwa sejatinya para pluralis mencetuskan agama baru. Merujuk pada teori civil religion sosiolog modern Amerika Robert N. Bellah yang dalam artikelnya yang berjudul "Civil Religion in America" menyebut yang berkembang di Amerika Serikat -sebuah negara pluralis demokratis- adalah agama civil, yaitu agama yang tidak berpihak pada agama-agama tradisional apapun yang dipeluk oleh warganya. Indikasinya adalah dalam pidato kenegaraan resmi setiap presiden Amerika selalu menyebut God, dan bukan nama tuhan agamanya seperti Jesus Christ dll. Dari sini Bellah menyimpulkan bahwa God disini adalah tuhannya rakyat Amerika keseluruhan tanpa memandang ras dan agama yang dianutnya ${ }^{10}$. Dengan analogi ini maka paham pluralisme menjadikan The Real-nya John Hick adalah tuhannya seluruh manusia penganut ke semua agama, sehingga pluralisme secara realitasnya adalah agama baru di luar agama-agama yang ada.

Secara kesejarahan, Anis menjelaskan pada dasarnya ide pluralisme agama muncul dengan latar belakang pertikaian antara madzhab-madzhab agama Kristen di akhir abad 19 yang menghebat sehingga sampai pada taraf mutual exclusion atau saling mengkafirkan diantara masing-masing kelompok sehingga presiden AS saat itu Grover Cloveland merasa perlu untuk turun tangan. Lalu pada awal abad 20, bermunculan macam-macam aliran fundamentalis di AS. Di tengah keriuhan ini seorang teolog Kristen bernama Ernst Troeltsch menggulirkan gagasan perlunya bersikap pluralis diantara aliran-aliran dalam agama Kristen maupun antara agama. Dalam artikelnya yang berjudul The Place of Christianity among the World Religions ia menyatakan bahwa umat Kristiani tidak berhak untuk mengklaim paling benar sendiri. Rupanya pendapat serupa telah dilontarkan sebelumnya oleh sejumlah pemikir dan teolog lain seperti sejarawan Arnold Toynbee dan tokoh Protestan Liberal Friedriech Schleiermacher. ${ }^{11}$

Dari semua ulasan diatas, diketahui bahwa pluralisme telah populer sebagai paham dengan makna ideologisnya, meninggalkan makna sosial yang pada dasarnya

9 DR. Anis Malik Thoha, Pluralisme Agama sama dengan Agama Baru, wawancara Henri Shalahuddin, Jurnal Islamia, Hermeneutika versus Tafsir Al-Qur'an, th. I, No. 1, Muharram 1425, hal. 100.

10 DR. Anis Malik Thoha, Pluralisme Agama sama dengan Agama Baru, wawancara Henri Shalahuddin, Jurnal Islamia, Hermeneutika versus Tafsir Al-Qur'an, hal. 101.

11 DR. Anis Malik Thoha, Pluralisme Agama sama dengan Agama Baru, wawancara Henri Shalahuddin, Jurnal Islamia, Hermeneutika versus Tafsir Al-Qur'an, hal. 98-99. 
menjadi makna aslinya. Seperti halnya terima radikal yang telah meninggalkan makna aslinya yaitu sifat secara mendasar, maju dalam berpikir dan bertindak. ${ }^{12}$ Sekarang ini kata tersebut mempunyai konotasi negatif yang lekat dengan rigiditas dan terorisme berwarna agama. Meminjam istilah Ushul Fiqih, arak telah menjadi cuka dalam kaidah istihalah. Maka hukum berbicara pada kenyataan yang ada bahwa dia telah menjadi cuka dan bukan kepada asal muasalnya yaitu arak. Dengan logika ini penulis menilai apa yang dijabarkan oleh MUI sudah sangat tepat dan sangat ditunggu oleh masyarakat, yaitu menjelaskan makna pluralisme seperti yang diklaim dan diimani oleh para tokoh pencetus paham ini sendiri, yaitu pluralisme dengan makna ideologisnya dan bukan sekedar makna sosialnya. Dan karena bagaimanapun juga pluralisme pada dasarnya memiliki makna sosial maka harus diberikan istilah lain yang membedakannya dengan makna populer yang pertama. Maka MUI melekatkan istilah pluralitas (fakta kemajemukan) atas makna sosial dari pluralisme dengan mewajibkan sikap inklusif dalam menghadapinya.

Hal ini lazim dilakukan untuk menghindari kerancuan paham. Seperti halnya dalam literatur Ilmu Hadits, ketika makna atsar mencakup pula makna hadits, yaitu yang dinisbatkan kepada Nabi shallallahu alaihi wa sallam. Akan tetapi makna atsar lebih populer sebagai penisbatan kepada selain beliau. Karenanya, untuk membedakan yang bersumber dari beliau dan dari yang selain beliau, maka Ulama memberikan aturan jika ingin menggunakan kata atsar untuk menyebut hadits haruslah dijelaskan dengan qayd atau yang menunjukkan maksud bahwa ini bersumber dari Nabi, yaitu dengan mengatakan: "..dan di dalam atsar dari Nabi shallallahu 'alaihi wa sallam....". Demikian pulalah MUI tidak menggunakan kata pluralisme begitu saja untuk makna pluralisme sosial karena terma ini telah menjelma sebagai makna ideologi secara fakta sebagaimana arak telah menjadi cuka, dan atau sebaiknya dengan memberikan kata penjelas bersamanya seperti pluralisme sosial keagamaan, pluralisme sosial kebhinnekaan dan seterusnya, sebagaimana memakai kata atsar untuk menisbatkan khabar kepada Nabi shallallahu 'alaihi wasallam harus disertai penjelasan.

Maka tidak menjadi persoalan sebenarnya ketika kelompok yang tidak setuju dengan isi dan redaksi fatwa MUI berkeberatan dengan persoalan terminologi kebahasaan pluralisme. Akan tetapi yang menjadi persoalan mereka tidak memberi solusi pilihan kata pengganti bagi istilah pluralisme bagi pluralisme ideologis ini yang tidak dapat dibantah telah diklaim tanpa embel-embel apapun oleh para tokohnya. Mereka hanya menyatakan tidak sepakat apabila pluralisme dimaknai dan dikonotasikan dengan persamaan dan relativitas kebenaran agama. Ahmad Muttaqien dalam artikelnya yang berjudul Rekonstruksi Pluralisme Agama (Telaah atas Buku Pluralisme Agama, Musuh Agama-agama Karya Adian Husaini) berkata:

"Penolakan agama terhadap pluralisme sesungguhnya bukan penolakan secara keseluruhan nilai yang terdapat pada pandangan pluralisme melainkan lebih pada pandangan teologis filosofisnya, dan penolakan pada dimensi ini tentunya bukanlah berarti harus harus menolak keseluruhannya. Disisi lain upaya menyamakan dan

${ }^{12}$ https://kbbi.web.id/radikal, diakses tanggal 20 Maret 2020. 
menyamaratakan masing-masing agama sebagaimana dikemukakan kelompok pluralis sesungguhnya bertentangan dengan prinsip pluralisme itu sendiri."13

Adapun Ulil Abshar Abdalla lebih berapologi dengan makanan asli kebahasaan walaupun ia tidak bisa memungkiri bahwa ia juga mendukung persamaan kebenaran agama-agama. "...pembedaan semacam ini salah tempat, keliru, dan tidak memiliki dasar argumen yang kuat. Mari kita telaah secara lebih cermat. Dalam kamus MeriamWebster, istilah pluralisme ditakrifkan sebagai berikut: the belief that people of different social classes, religions, races, etc., should live together in a society. Benar, pluralisme adalah sebuah ide - yaitu ide bahwa masyarakat bisa hidup bareng dalam sebuah komunitas, walau mereka memiliki perbedaan-perbedaan, entah ras, agama, atau kelas sosial." 14

Selanjutnya ia menjelaskan hakikat pluralisme dan pluralitas. "Pluralisme dan pluralitas adalah dua hal yang tidak bisa dipisahkan; dua sisi dari koin yang sama. Menerima pluralitas saja, tetapi menolak pluralisme, adalah sikap yang tidak masuk akal. Jika kita hanya menerima pluralitas saja, itu sekedar pengakuan bahwa masyarakat secara faktual memang berbeda. Yang dibutuhkan bukan pengakuan seperti itu. Mengakui bahwa masyarakat adalah entitas sosial yang beragam bukanlah hal yang istimewa."15 Disini ia menekankan pluralitas sebagai sekedar fakta perbedaan, sedangkan pluralisme adalah kelanjutan sikap dari realita perbedaan tersebut. Dipahami disini penjelasan MUI bahwa pluralitas atau fakta perbedaan harus disikapi dengan pergaulan inklusif yang akomodatif terhadap kemaslahatan bersama tidak dapat ia terima karena hanya berbentuk keterangan tambahan saja, dengan mengeliminir istilah yang sebenarnya.

Pada saat yang sama ia juga menunjukkan pemikirannya yang pro persamaan kebenaran tataran tertinggi (aqidah) agama: "Bahwa ada suatu ide mengenai kesamaan transendental antara agama-agama, seperti pernah dikemukakan oleh filosof Swiss Frithjof Schuon, memang benar. Saya sendiri punya pandangan serupa: bahwa agama, secara transendental dan esensial, pada dasarnya sama. Perbedaan hanya terjadi pada aspek manifestasi dari "esensi transendental" itu dalam bentuk doktrin, syariat atau aturan-aturan normatif. Tetapi pandangan ini adalah hal yang ada di luar pengertian pokok tentang pluralisme." 16

Sampai disini, kesimpulannya adalah ia ingin mengatakan bahwa kata pluralisme tidak hanya mencakup relativitas agama yang merupakan paham yang ia percayai, tetapi juga mencakup makna toleransi yang tidak ala kadarnya sebagai sikap terhadap fakta pluralistis yang ada. Bagi penulis hal ini menimbulkan pertanyaan atas alasannya kuat mengkritik hasil fatwa MUI terkait persoalan ini.

\footnotetext{
${ }^{13}$ Ahmad Muttaqien, Rekonstruksi Gagasan Pluralisme Agama, Jurnal Al-Adyan, hal.109

14 Ulil Abshar Abdalla, Pluralisme dan Pluralitas: Dua Sisi Dari Koin Yang Sama, https://islamlib.com/topik/pluralisme/, diakses tanggal 20 Maret 2020.

15 Ulil Abshar Abdalla, Pluralisme dan Pluralitas: Dua Sisi Dari Koin Yang Sama, https://islamlib.com/topik/pluralisme/, diakses tanggal 20 Maret 2020.

16 Ulil Abshar Abdalla, Pluralisme dan Pluralitas: Dua Sisi Dari Koin Yang Sama, https://islamlib.com/topik/pluralisme/, diakses tanggal 20 Maret 2020.
} 


\section{Pandangan Para Pengusung Pluralisme Agama di Indonesia.}

Dengan memahami makna terima pluralisme dari makna bahasa dan sejarah perkembangan ideologisnya, mengukur permasalahan akademisi dan sosial pluralisme di Indonesia yang menyebabkan MUI berusaha menarik benang merah dengan fatwanya adalah dengan mengetahui ide-ide pemikiran para tokoh-tokoh nasionalnya. Seperti yang dikemukakan Syafii Ma'arif, pluralistis adalah suatu keanekaragaman yang ada dalam suatu masyarakat yang mengakui bahwa hal yang lain ada di luar kelompoknya. Sedangkan pluralisme bukan sekedar fakta atau keadaan yang bersifat plural akan tetapi suatu sikap yang mengakui sekaligus menghargai dan menghormati bahkan mengembangkan dan memperkaya keadaan yang bersifat plural. ${ }^{17}$

Pengertian ini masih memberikan posisi samar bagi toleransi apakah berada pada pluralistis araukah pluralisme. Menurut Budy Munawar Rachman, pluralisme agama lebih dari toleransi, dimana ia mengandaikan pengenalan secara mendalam atas yang lain sehingga ada mutual understanding yang membuat satu sama lain secara aktif mengisi toleransi dengan hal yang lebih konstruktif, bersama membangun peradaban ${ }^{18}$. Ia juga menegaskan bahwa pluralisme agama bukanlah relativisme seperti pernyataan simplistis bahwa semua agama sama saja. Karena justru perbedaan itulah yang menjadi potensi besar untuk membangun peradaban ${ }^{19}$. Akan tetapi kemudian di tempat yang sama dia menyatakan berkebalikan, yaitu menurutnya secara teologis pluralisme agama ini berarti bahwa manusia memang harus menangani perbedaan-perbedaan mereka dengan cara terbaik (fastabiq al khairaat) secara maksimal sambil menaruh penilaian akhir kebenaran kepada Tuhan, karena tidak ada satu cara pun yang bisa dipergunakan secara objektif untuk mencapai kesepakatan mengenai kebenaran yang mutlak ini. ${ }^{20}$

\footnotetext{
17 Ma'arif dalam Catur Widiat Moko, Pluralisme Agama Menurut Nurcholis Madjid (1939-2005) dalam Konteks Keindonesiaan, Medina-Te, Vol. 16, No. 1, Juni 2017, hal. 64.

18 Budhy Munawwar Rachman, Perspektif Global Islam dan Pluralisme, Ilmu Ushuluddin, Vol. 1, No. 3, Januari 2012, hal. 216.

${ }^{19}$ Budhy Munawwar Rachman, Perspektif Global Islam dan Pluralisme, Ilmu Ushuluddin, hal. 216. Maksud dia dengan perbedaan yang lazim itu terletak pada kenyataan bahwa semua agama berbeda dalam aqidah dan syariatnya (hal. 217), namun pernyataan-pernyataan lengkap dia dalam makalah tersebut menyimpulkan gagasannya bahwa berbeda aqidah dan syariah tidak berarti berbeda nilai kebenaran bagi semua agama-agama.

${ }^{20}$ Iapun menguatkan pendapatnya ini berdasarkan Q.S 2: 113; 3: 55; 5: 48; 6: 164; 10: 93; 16: 92, 124; 22: 69; 32: 25; 39: 3, 46; 45: 17. Budhy Munawwar Rachman, Perspektif Global Islam dan Pluralisme, Ilmu Ushuluddin, hal. 216.

Semua ayat-ayat yang disebutkan sebagai landasan tersebut mempunyai kesamaan kandungan yaitu janji Allah untuk memperlihatkan hakikat perkara yang diperselisihkan. Hal ini menurut penulis tidak mempunyai relevansi dengan pluralisme karena pertama, mengabaikan konteks yang sebenarnya. Seperti kaitan ayat dengan ayat sebelumnya dalam Q.S 22: 69. Pada ayat 68 diajarkan kepada Nabi menjawab mereka yang membantahnya, bahwa Allah Mengetahui apa yang mereka kerjakan. Maka dasar kebenaran dan kebatilan telah ditetapkan disini, sehingga janji Allah untuk memperlihatkan hakikat yang diperselisihkan di akhirat tidak keluar dari ketetapan tersebut. Bahkan mengabaikan konteks yang jelas disebutkan oleh ayat yang sama seperti dalam Q.S 45:17, yang menegaskan sebab perselisihan tersebut tidak lain adalah kedengkian atas kebenaran yang ditunjukkan, sehingga jelaslah sebenarnya antara kebenaran dan kebatilan tersebut semenjak di dunia. Dan lain-lain yang menunjukkan bahwa konteks
} 
Sikap Budhy Munawar ini representasi sikap rata-rata para pengusung pluralisme ideologis di Indonesia -termasuk Ulil Abshar diatas yang berapologi dengan terma pluralisme yang dilarang oleh MUI dengan menyajikan pluralisme kepada masyarakat sebagai makna asalnya yang umum sedangkan mereka sendiri meyakininya sebagai makna ideologis.

Budhy juga mengangkat konsep Ahl al Kitab dalam Islam sebagai landasan pluralisme. Bahwa menurutnya konsep ini menunjukkan bahwa Islam tidak serta merta mengelompokkan non muslim sebagai kafir. Al-Qur'an mengkategorikan orangorang Yahudi dan Nasrani sebagai Ahl al Kitab yang mempunyai kedudukan setara di hadapan Tuhan dengan kaum muslim. Konsep ini berdampak pada kerjasama perkembangan budaya dan peradaban gemilang, dengan penaklukan wilayah-wilayah dan diiringi pernikahan lintas agama tanpa harus mencampuri agama masing-masing. "Kebolehan umat Islam memakan sembelihan ahl al kitab dan menikahi kaum perempuan mereka (Q.S 4:5) seperti terjadi dalam sejarah Islam mengisyaratkan bahwa secara umum pergaulan akrab muslim dengan non muslim telah berlangsung dengan baik dan penuh toleransi, walaupun banyak hal yang harus dikembangkan lebih lanjut jika dilihat dari kacamata ide-ide toleransi dan pluralisme agama kontemporer". ${ }^{21}$ Yang terakhir ini menunjukkan bahwa pluralisme agama kontemporer menurutnya selalu bebas mengembangkan segala konsep dalam agama yang mana menurut penulis mengarah pada relativisme. Ia bercermin pada apa yang dilakukan Muhammad Rasyid Ridha yang memperluas konsep ahl al kitab bukan hanya untuk Yahudi dan Nasrani tetapi juga Zoroaster atau Majusi, dan Buddha yang mempunyai kitab suci. 22

ayat-ayat yang dijadikan sandaran tersebut tidak relavan dengan pluralisme. Kedua, secara akal penjelasan akan hakikat dunia di masa depan yakni akhirat tidaklah selalu berarti tidak diketahui sebelumnya di dunia. Atau, sebab dijelaskannya hakikat di akhirat bukanlah karena tidak jelasnya masalah di dunia, tetapi sebagai penguatan atas kebenaran yang disampaikan di dunia dan hiburan bagi orang beriman agar tetap teguh menghadapi mereka yang tidak berhenti membantah dan menyelisihi, bahwa Allah akan menunjukkan kebenaran tersebut tanpa dapat dibantah lagi oleh para pembangkang.

${ }^{21}$ Budhy Munawwar Rachman, Perspektif Global Islam dan Pluralisme, Ilmu Ushuluddin, hal. 217218.

${ }^{22}$ Rasyid Ridha mendasarkan gagasannya kepada pendapat Abu Hanifah bahwa kaum Sabi'ah menyerupai ahl al kitab sementara Abu Saur menyatakan bahwa Majusi juga demikian. Kedua pendapat tersebut berbeda dengan pendapat mayoritas ulama yang menyatakan bahwa kedua kelompok tersebut hanya disamakan dengan ahl al kitab dalam masalah jizyah, tidak pada hal-hal yang lain seperti memakan sembelihan mereka dan menikahi kaum perempuannya. Ridha juga mengatakan beberapa Ulama -tanpa menyebutkan nama- yang berpendapat bahwa Majusi dan Shabiah tidak hanya menyerupai ahl al kitab tetapi termasuk ahl al kitab karena pada dasarnya mereka mempunyai kitab suci namun telah lenyap karena terlalu lama dari zaman Nabi mereka. Ridha menyetujui pendapat terakhir ini dan menyatakan bahwa Al-Qur'an hanya menyebut Shabi'ah dan Majusi, dan tidak menyebut agama-agama kuno lain seperti Hindu, Budha dan Konfusius, ini karena orang-orang Arab saat itu belum pernah sampai ke wilayah Jepang, Cina dan India sehingga tidak mengenal agama-agama tersebut. Dengan demikian menurut Rasyid Ridha, semua kelompok agama yang memiliki kitab suci yang diduga berasal dari seorang nabi, walaupun isi kitab suci tersebut telah menyimpang dari aslinya, dapat dimasukkan ke dalam kelompok ahl al kitab. (Muhammad Rasyid Ridha, Tafsir Al-Qur'an Al Hakim, Beirut: Dar al Fikr, 1973, Juz. III hal. 258 , Juz. VI hal. 179, dan Juz. VI hal. 185,186, 188, 190). Pendapat Ridha ini berbeda dengan pandangan gurunya, Muhammad Abduh, sebagaimana diungkapkan dalam tafsir Juz Amma-nya, yang menyatakan bahwa ahl al kitab mencakup penganut agama Yahudi, Nasrani dan Shabi'ah, 
Akan tetapi menurut penulis, terlepas setuju dan tidaknya dengan pendapat Rasyid Ridha tersebut, pengembangan konsep Ahl al Kitab kepada selain Yahudi dan Nasrani justru semakin memperkuat bahwa tujuan konsep ini adalah dakwah, dan bukan persamaan pluralisme ideologis, karena ketiadaan kalimat sawa' antara para penyembah api dan kaum muslimin seperti halnya Yahudi dan Nasrani. Karena apabila konsep ahl al kitab yang berdasarkan kalimat sawa atau titik temu sebagai sesama millah Ibrahim ini menjadi tolok ukur kebenaran ketiga agama setelah datangnya Islam dan menjadi alasan diperbolehkannya pernikahan lintas agama dan memakan makanan mereka, maka gagasan Rasyid Ridha ini sulit difahami dengan dasar. Juga, apabila titik temu tersebut sebagai tolok ukur kebenaran dan berimplikasi kepada kebenaran semua agama tentulah pernikahan lintas agama yang diperbolehkan dalam Islam tidak terbatas pada menikahi wanita-wanita ahl al kitab saja tetapi juga prianya. Nyatanya pembatasan tersebut bukan tanpa alasan, bahkan ia sebagai prevensi dominasi akidah dari pasangan non muslim. Dan nampaknya masalah pembatasan inilah yang dimaksudkan oleh Budhy Munawar yang harus dikembangkan sesuai ide-ide pluralisme agama kontemporer di atas.

Ayat Al-Qur'an yang selalu diklaim oleh para pluralis adalah Q.S Al-Maidah/ 5: 69 “Sesungguhnya orang-orang Mu'min, orang-orang Yahudi, orang-orang Nasrani, dan orang-orang Shabi'un, siapa saja yang diantara mereka yang benar-benar beriman kepada Allah dan hari akhirat dan beramal shalih mereka akan mendapatkan pahala dari Tuhan mereka, mereka tidak perlu khawatir dan bersedih". Ayat ini oleh jumhur ulama tafsir disebut hanya mengacu kepada Yahudi dan Nasrani sebelum kenabian Muhammad shallallahu 'alaihi wasallam, dan diperkuat dengan Q.S 3: 85 bahwa agama yang diterima oleh Allah hanyalah agama Islam. Akan tetapi hal ini dibantah oleh Budhy Munawar dengan mengutip pendapat Jalaluddin Rakhmat bahwa kosakata Islam dalam Q.S 3: 85 bukan menunjuk kepada Islam sebagai agama formal yang dibawa oleh Nabi Muhammad shallallahu 'alaihi wasallam, tetapi mengacu pada Islam dalam pengertian umum yakni sikap pasrah kepada Tuhan yang merupakan misi segenap risalah langit23. "Pengertian demikian akan terlihat pula dalam ayat "Ingatlah ketika Tuhannya berkata kepadanya (Ibrahim), Islam-lah (pasrahlah) engkau!" Dia (Ibrahim) menjawab: "Aku Islam (pasrah) kepada Tuhan pemelihara alam semesta." Q.S 2: $131^{\prime \prime} .{ }^{24}$

Bagi penulis, ada yang menarik ketika Al-Qur'an berbicara tentang Nabi Ibrahim 'alaihissalam berkenaan dengani hal ini. Allah menegaskan dalam Q.S Al Hajj 78 bahwa nama muslim telah diberikan sedari awal oleh Allah bagi umat Muhammad yang diperintahkan untuk mengikuti agama bapak mereka Ibrahim: "(Ikutilah) agama bapakmu Ibrahim. Dia (Allah) telah menamai kamu sekalian orang-orang muslim dari dahulu dan (begitupula) dalam (Al-Qur'an) ini." Demikian pula sebutan bagi Ibrahim dalam Q.S 3: 67 sebagai seorang yang lurus lagi berserah diri (muslim), sembari menafikan dugaan atasnya sebagai seorang Yahudi, Nasrani maupun musyrik.

sebagaimana diungkapkan secara implisit Q.S Al Baqarah: 2/62. (Muhammad Abduh, Tafsir Al Qur'an al Karim Juz Amma, Kairo: Dar wa Matabi' al Sya'b, t.t, hal. 101.)

${ }^{23}$ Budhy Munawwar Rachman, Perspektif Global Islam dan Pluralisme, Ilmu Ushuluddin, hal. 224

${ }^{24}$ Budhy Munawwar Rachman, Perspektif Global Islam dan Pluralisme, Ilmu Ushuluddin, hal. 224 
"Ibrahim bukanlah seorang Yahudi dan bukan pula seorang Nasrani, akan tetapi dia adalah seorang yang lurus lagi berserah diri (kepada Allah) dan sekali-kali bukanlah dia termasuk golongan orang-orang musyrik". Yang dapat dipahami disini, kosakata Islam dan muslim baik sebagai agama maupun sifat disematkan kepada Nabi Ibrahim dan umat Muhammad dan tidak kepada Yahudi maupun Nasrani. Jika tidak maka tidak akan ditegaskan penafian keadaan Ibrahim sebagai Yahudi dan Nasrani. Dan Allah tidak memberi nama Yahudi dan Nasrani kepada umat Nabi Musa dan Nabi Isa 'alaihimassalam seperti menamai muslim kepada umat Muhammad. Maka secara sifat tentu saja Nabi Musa dan Nabi Isa dan orang-orang shalih yang mengikutinya tidak berbeda dari agama atau millah Ibrahim, tetapi sebutan Yahudi dan Nasrani tidak datang dari Allah sedari awal seperti halnya sebutan muslim. Terlebih ketika kedua agama tersebut telah mengalami penyelewengan. Maka menjadi rasional sekali apabila dalam kacamata Islam nilai kebenaran ketiga agama tersebut tidak dapat disamakan. Yang sama benarnya adalah agama Nabi Musa, Nabi Isa dan Nabi Muhammad yang kesemuanya sesuai dengan millah Ibrahim. Disinilah letak larangan bercerai berai sesama pengikut millah Ibrahim dalam ajaran-ajaran yang berbeda-beda. Maka ketika Nabi Isa diutus diperintahkan kepada pengikut agama para Nabi sebelumnya mengikutinya, dan ketika Nabi Muhammad diutus diperintahkan kepada pengikut agama para Nabi sebelumnya mengikutinya. Maka ajaran samawi ini bersifat estafet dan bukan paralel seperti yang disebut oleh para pluralis. Disamping itu, jawaban bahwa yang dimaksud oleh Q.S 3: 85 adalam Islam sebagai kosakata sifat adalah lemah. Karena jelas konteks ayat tersebut sedang berbicara tentang agama (Din), bukan sifat ataupun sikap seperti ketika berbicara tentang sikap Nabi Ibrahim-, dan menyandingkannya dengan al-Islam. Dengan demikian tentu saja yang dimaksud adalah Islam sebagai agama formal. Maka disana dengan tegas Al-Qur'an berkata: "Dan barangsiapa mencari agama selain agama Islam, maka sekali-kali tidaklah akan diterima (agama itu) daripadanya".

Pemaknaan Islam sebagai kosakata ini oleh para pluralis diperlebar kepada semua agama-agama formal, karena menurut mereka yang menjadi ukuran adalah beriman kepada Tuhan dan hari akhir serta amal shalih" ${ }^{25}$. "Tidak ada nama dan tidak ada sifat yang bisa memberi kebaikan jika tidak didukung oleh iman dan amal shalih. Aturan ini berlaku untuk semua umat manusia. Keselamatan tidak dapat ditemukan dalam sektarianisme keagamaan tetapi dalam keyakinan yang benar dan kebajikan." 26

Sejalur pendapat ini adalah Nurcholish Madjid, "kaum muslim" adalah kaum yang ber-Islam, yang tunduk patuh, pasrah, dengan kedamaian (salam) kepada Tuhan, sebagaimana kaum mu'min (orang Islam) yang beriman sepenuhnya percaya kepada Tuhan"27 Ia juga menafsirkan syariat yang sama dalam semua agama dalam Q.S 42:13. "jika dicermati firman itu maka jelas bahwa syariat itu sama pada semua agama yaitu pada pengertian-pengertian fundamental itu dan tidak boleh berpecah belah. Juga seruan ini teramat berat pada orang orang musyrik. Ini disebabkan mereka itu tidak

\footnotetext{
${ }^{25}$ Budhy Munawwar Rachman, Perspektif Global Islam dan Pluralisme, Ilmu Ushuluddin, hal. 224

${ }^{26}$ Jalaluddin Rakhmat, Islam dan Pluralisme, Akhlak Qur'an menyikapi Perbedaan, Jakarta: Serambi, 2006, hal. 32-34.

${ }^{27}$ Nurcholish Madjid, Indonesia Kita, Jakarta: GramediaPustaka Utama, 2003, hal. 42.
} 
mengerti atau tidak sanggup memahami bahwa pada dasarnya agama-agama itu adalah satu, dan semua Nabi dan Rasul Tuhan mengajarkan hal yang sama yaitu ajaran kepatuhan kepada Tuhan (din Allah), yang kepatuhan itu harus dilakukan dengan sikap pasrah dan tulus dengan rasa damai (yaitu Islam atau al-islam dalam pengertiannya yang paling dasar)" ${ }^{28}$ Penjelasan ini menyisakan ambigu karena jika yang dimaksud hal fundamental dalam ayat tersebut adalah tunduk, patuh, pasrah dan percaya sepenuhnya kepada Tuhan, maka baik penganut agama samawi maupun agama filsafat bahkan musyrikin sekalipun merasakan semua itu. Akan tetapi jika melihat konteks ayat tersebut membandingkan ajaran fundamental agama samawi dengan aqidah musyrikin, maka jelas perbedaannya ada pada kemurnian aqidah dan lurusnya syariah. Maka tentu saja perbedaan kasat mata antara keduanya dalam aqidah adalah tauhid dan syirik. Dan tauhid inilah hal fundamental yang mendasari syariat Nabi Nuh, Nabi Ibrahim, Nabi Musa dan Nabi Isa serta Nabi Muhammad Shallallahu 'alaihi wasallam. Maka diperintahkan untuk menegakkan tauhid itu dan dilarang berpecah belah diantara mereka semua dengan mengikuti syariat Nabi yang datang pada masanya. Seruan kepada tauhid ini sangat berat bagi musyrikin yang tidak mempunyai mental bergantung hanya kepada Tuhan yang satu saja.

Demikianlah pandangan para pendukung ide pluralisme di Indonesia. Disimpulkan dari uraian diatas yang mereka maksudkan dengan pluralisme agama adalah persamaan kebenaran agama-agama yang tentu saja dapat merusak dasar akidah keimanan agama apapun yang pada dasarnya mengimani kebenaran eksklusif dan menjadi dasar konsekwensi mereka dalam menentukan keyakinannya. Kenyataan ini menjadi pijakan MUI untuk mengeluarkan fatwa dan melihat urgensi pembedaan antara terma pluralisme dan pluralitas meskipun secara dasar kebahasaan bermakna umum, sebelum ia menjadi diskursus spesifik keagamaan dan lekat sebagai sebuah pemikiran filsafat agama yang baru.

Sedangkan Abdurrahman Wahid atau Gus Dur, yang disebut-sebut sebagai bapak pluralisme memandang pluralisme agama dalam konteks ajaran universalisme dan kosmopolitanisme dalam Islam. Hal ini tampak pada lima jaminan dasar yang diberikan Islam kepada warga masyarakat baik secara personal maupun kelompok, yaitu: 1) Keselamatan fisik warga masyarakat dari tindakan badani diluar ketentuan hukum; 2) Keselamatan keyakinan agama masing-masing tanpa ada paksaan untuk berpindah agama; 3) Keselamatan keluarga dan keturunan; 4) Keselamatan harta benda dan milik pribadi diluar prosedur hukum; dan 5) Keselamatan profesi ${ }^{29}$. Menurut penulis, pandangan pluralisme Gus Dur ini dapat dipahami sebagai bentuk usaha beliau sebagai kepala negara saat itu untuk mempertahankan integrasi nasional. Maka beliau berupaya mencegah segala potensi yang menurut beliau dapat merubah bentuk NKRI dari bentuk aslinya seperti penyikapan terhadap konflik keagamaan yang telah penulis singgung diatas. Beliau mengatakan, adalah tidak bijaksana untuk mementingkan pandangan sektarian yang hanya mengutamakan kebenaran pihak

${ }^{28}$ Nurcholish Madjid, Atas Nama Pengalaman Beragama dan Berbangsa di Masa Transisi, Kumpulan Dialog Jum'at di Paramadina, Jakarta: Paramadina 2002, hal. 54.

29 Ma'arif dalam Catur Widiat Moko, Pluralisme Agama Menurut Nurcholis Madjid (1939-2005) dalam Konteks Keindonesiaan, Medina-Te, hal. 64. 
sendiri belaka dengan membahayakan proses integrasi nasional. Akibatnya adalah keretakan yang mungkin tidak akan dapat dijembatani lagi, misalnya antara "golongan Islam" dan golongan-golongan lain diluarnya. ${ }^{30}$

Yang lebih tampak adalah pemikiran sekuler yang diperlihatkan oleh beliau. Ketika beliau lebih memprioritaskan permasalahan sosial dan ekonomi, beliau memandang nilai-nilai etik dan kerja semestinya lebih diutamakan ketimbang mempermasalahkan apakah seorang muslimah harus mengenakan jilbab atau tidak ${ }^{31}$. Sedangkan, bahwa beliau mengusung pluralisme ideologis keagamaan atau persamaan kebenaran semua agama tidak terlihat dalam pemikiran beliau. Bahkan beliau sebenarnya membuka celah bagi kehidupan agamis masyarakat melalui "pintu" beraroma ide sekuler yang dilontarkannya: "ada persamaan tujuan antara negara sekuler dan negara Islam, yaitu sama-sama melindungi hak-hak pribadi para warga negaranya. Apabila jalan pikiran ini diikuti dengan konsekwen, maka yang menjadi ukuran satu-satunya baik negara Islam maupun sekuler adalah kesejahteraan warga negara secara perorangan, dan selebihnya hanyalah bentuk luar yang dapat saja diubah oleh rakyat melalui lembaga perwakilan mereka. ${ }^{32}$ Dengan demikian beliau mempersilahkan dan mendukung upaya politis di parlemen untuk mewujudkan kepentingan agama masyarakat. Gus Dur sendiri pada masa pemerintahannya meliburkan sekolah selama bulan Ramadhan, yang tidak dilanjutkan pemerintahanpemerintahan setelahnya.

\section{Pluralisme Sosial Keagamaan untuk Mewujudkan Moralitas Bangsa yang Shalih.}

Seperti yang telah disinggung di awal, pluralitas atau kemajemukan masyarakat telah menjadi identitas bangsa ini. Menjadi tugas bersama seluruh elemen untuk menjadikan kemajemukan ini sebagai sebuah harmoni yang sesungguhnya, harmoni yang tidak melukai prinsip satupun unsur kemajemukan di dalamnya. Dalam sejarah penataan masyarakat majemuk secara harmonis telah dilakukan Nabi shallallahu 'alaihi wa sallam sendiri di Madinah, dimana setiap agama diberikan otoritas hukum bagi para pemeluknya masing-masing. Dalam sebuah hadits disebut bagaimana orang Yahudi berzina dihukum rajam berdasarkan yang tertera dalam Taurat. ${ }^{33}$ Kaum Yahudi sendiri mengakui bahwa berabad-abad lamanya mereka hidup dalam naungan Islam dalam keadaan selamat dan aman sehingga turut berpeluang untuk menyumbang kegemilangan peradaban Islam. Umat Islam tidak menunjukkan rasa kebencian dan permusuhan atas dasar etnik atau ras, tidak ditindas, tidak diteror dan tidak dirampas haknya sebagai manusia. Mereka hanya dikecam karena memilih

\footnotetext{
${ }^{30}$ Abdurrahman Wahid, Prisma Pemikiran Gus Dur, Yogyakarta: LKiS, 2010, hal. 165.

31 Saiful Muzani, Mitos Politik dan Aspirasi Politik ICMI Modernis, Book Review, Adam Schwarz, "Islam: Coming in from the cold?, dalam bukunya, A Nation in Waiting, Indonesia in the 1990's, (Sydney: Allan and Urwin, 1994), Studia Islamika, Vol. 2, No. 1, 1995, hal. 223.

32 Abdurrahman Wahid, Bercermin Dari Para Pemimpin, dalam Abdul Mun'im D.Z. (ed), Islam di Tengah Arus Transisi, Jakarta: Kompas, 2000, hal. 287.

33 Al Bukhari, Muhammad Ibnu Isma'il, al-Jami'al-Musnad as-Shahih Min Umuri Rasulillahi shallallahu 'alaihi wasallam Wa Sunanihi Wa Ayyamihi, atau Shahih Al-Bukhari, Beirut: Dar Ibni Katsir, 2002, jilid. 6, hal. 37, No. 4556, bab Qul Fa'tu bi at-Taurati fatluha in kuntum shadiqin (Q.S Ali ‘Imran:3/93)
} 
kekufuran setelah diberi penjelasan dan kesempatan. Mereka diberi hak hidup sesuai ajaran agama dan bidang profesinya. Berbeda dengan pengalaman mereka hidup dibawah pemerintahan raja-raja Kristen Eropa dimana mereka diperlakukan sangat buruk bahkan diusir ${ }^{34}$.

Otoritas hukum bagi setiap agama ini juga diberlakukan selama berabad-abad era kekhalifahan Turki Utsmani yang disebut dengan sistem Millet. Sistem millet ini diterapkan sejak masa Khalifah Usman I ini diberlakukan kepada kelompok agama dan suku minoritas dengan diberikannya hak privasi tanpa intervensi dari pemerintah pusat Ottoman. Seorang Kristen diadili oleh Gereja dan seorang Yahudi diadili oleh para rabi. Millet ini memberi penekanan pada hal penting yang sering diabaikan di dunia modern yaitu otonomi komunal. $^{35}$ Sayangnya sistem ini dihapus saat pemerintah Turki Usmani memerintah dengan sistem sekuler mendekati akhir 1700$\mathrm{an}^{36}$.

Menilik semua fakta sejarah dapat disimpulkan bahwa kemajemukan lazim terjadi dan menjadi sunnatullah, dan konsistensi masyarakat kepada agama masingmasing menjadikan masyarakat agamis, bermoral dan berkualitas. Mendekatkan masyarakat kepada agamanya masing-masing berarti mendekatkan mereka kepada moralitas yang penting untuk membangun peradaban tinggi. Pertanyaannya, apa sajakah titik perbedaan kesamaan kondisi bangsa Indonesia dengan komunitas terdahulu? Kesamaaan angka populasi, keluasan wilayah, tingkat kemajemukan Indonesia hampir dapat dikatakan sama dengan Turki Utsmani. Yang membedakan adalah dasar negara ini bukanlah Islam dan berbeda dengan Turki Utsmani saat itu. Dan juga posisi non muslim di Indonesia sejajar bukan sebagai ahli dzimmah. Tentu saja harus dicarikan formula lain yang lebih sesuai.

Beberapa poin yang nampaknya penting menurut penulis dalam membangun masyarakat majemuk yang agamis atau pluralisme sosial keagamaan.

Hal pertama yang sangat penting dalam pluralitas adalah masing-masing anggota masyarakat plural harus mengenal dan menegaskan identitasnya, agar betul memahami dimana posisi dirinya di dalam pluralitas tersebut. Sehingga dia mengerti apa saja perbedaan dan alasan mengapa dirinya berbeda dengan yang lain, sehingga dengan itu dia dapat menempatkan diri, mengenali, memahami dan menghargai posisi yang lain. Ibarat seorang penduduk daerah yang harus tahu betul letak dan posisi rumahnya diantara rumah-rumah masyarakat karena dia bagian dari mereka. Sehingga dia mengerti, memahami dan menghormati yang bukan rumahnya, disamping dia juga harus menegaskan dia pemilik rumahnya sendiri yang menjadi hak dan identitasnya.

${ }^{34}$ Syamsuddin Arif," Interfaith Dialogue" dan Hubungan Antaragama dalam Perspektif Islam", Jurnal Tsaqafah hal. 159

35 https://republika.co.id/berita/ps0674313/sistem-millet-mulai-berlaku-di-masa-usman-i, diakses tanggal 20 Maret 2020

${ }^{36}$ https://republika.co.id/berita/n91u2942/menjaga-hak-dan-kewajiban, diakses tanggal 20 Maret 2020 
Sikap abu-abu dalam kemajemukan berbahaya dan kontraproduktif bagi kemajemukan itu sendiri, karena berpotensi kepada kesalahkaprahan tindakan yang berpotensi melukai sebagian anggotanya.

1. Diberikannya otonomi hukum bagi masing-masing agama dan memberlakukannya kepada masing-masing penganutnya. Menentukan undang-undang bagi pengikutnya, mewajibkan masing-masing untuk menjalankan agama dan menindak pelanggarnya.

2. Sikap pemerintah yang objektif menyikapi kemajemukan dan pluralitas agama yang ada sehingga mengerti kemana seharusnya ia mengembalikan persoalan yang beririsan dengan salah satu atau beberapa agama kepada otoritas masingmasing dan menjadi partner mereka mempertimbangkan permasalahan sesuai kemaslahatan.

3. Fungsi pemerintah sebagai fasilitator dan pendukung sekaligus pelindung serta penjamin keamanan, kenyamanan, dan kelancaran bagi keagamaan dan keberagaman masyarakat. K.H Abdurrahman Wahid berkata: Negara hanya bersifat membantu, justru masyarakat yang harus berperan menentukan hidup matinya agama tersebut di negeri ini. Disinilah terletak firman Allah: "Tak ada paksaan dalam beragama (karena) benar-benar telah jelas mana yang benar mana yang palsu" (QS. Al-Baqarah: 2/256) ${ }^{37}$

4. Pemerintah bukanlah sekelompok penganut ideologi pluralis dan menyamaratakan kebenaran semua agama dan sekedar menjadi wasit atau penjaga, karena mereka juga bagian dari kemajemukan yang menganut asas pemersatu yakni Ketuhanan Yang Maha Esa. Para pejabat pemerintah wajib pula menentukan pilihan agama dengan konsisten bertanggungjawab, dan memahami posisi jabatannya yang harus digunakan untuk menegakkan keadilan bagi semua elemen.

Apabila pemerintah tidak menyamakan keadaannya dengan anggota masyarakat lain dalam beragama maka yang terjadi adalah republican banquet-nya William James, dimana setiap pluralisme selalu mengandaikan adanya host culture atau tuan rumah budaya yang menerima dan menjamu semua budaya yang datang ${ }^{38}$. Apabila kondisi ini diberlakukan maka yang terjadi adalah Civil Religion sebagaimana yang telah dikutip dari Robert N. Bellah dalam makalah ini sebelumnya.

Posisi Pancasila adalah asas pemersatu, yang sesuai dengan ajaran semua agama masyarakat, sehingga dia sah untuk dimiliki dan dihargai oleh semua masyarakat penganut tiap agama. Dengan demikian tidak akan muncul penganut agama pancasila. Asas Pancasila yang telah disepakati bangsa ini seharusnya memberikan efek krusial terhadap kehidupan masyarakat bernegara. Aktualisasi Pancasila hendaknya diperjuangkan, karena tujuan merumuskan Pancasila agar kehidupan berbangsa tidak hilang arah. Jika tidak dimaksimalkan fungsinya untuk mewujudkan kemaslahatan maka perumusan Pancasila sia-sia belaka. yang paling urgen untuk menata bangsa adalah pembangunan kualitas pribadi manusianya.

${ }^{37}$ Abdurrahman Wahid, Islamku Islam Anda Islam Kita, Jakarta: Wahid Institute, 2006, hal. 154

38 DR. Anis Malik Thoha, Pluralisme Agama sama dengan Agama Baru, wawancara Henri Shalahuddin, Jurnal Islamia, Hermeneutika versus Tafsir Al-Qur'an, hal. 100 
Sedangkan Pancasila berkata setiap warga haruslah berketuhanan, beriman kepada Tuhan Yang Maha Esa. Maka masing-masing harus mengimani agamanya dengan penuh bertanggung jawab apapun pilihan agamanya. Karena agama walaupun pada tataran tertingginya (aqidah) tidaklah sama dan merupakan pilihan dan kebenarannya menjadi tanggungjawab mutlak masing-masing individu, namun pada tataran terendah out put ajarannya dalam ranah sosial tidak bertentangan dengan nilai kebenaran universal. Sedangkan dalam ranah ritual ibadah menjadi urusan pribadi masing-masing seperti dalam hal aqidah beserta klaim kebenarannya.

Sila pertama Pancasila menuntut tiap warga negara menjadi individu agamis. Apabila hal ini terlaksana maka dapat dibayangkan betapa rapinya bangsa yang multi agama ini dengan manusia-manusianya yang shalih, jujur, bermoral dan bertanggungjawab.

\section{KESIMPULAN}

Pluralisme memiliki semua arti: keadaan plural, toleransi, kemajemukan prinsip tertinggi, relativitas kebenaran. Munculnya pluralisme sebagai ideologi filsafat menjadikan kata ini lekat dengan makna ideologisnya yaitu relativitas kebenaran agama. Seperti halnya radikalisme yang telah meninggalkan makna aslinya dan menjadi berkonotasi kekerasan berwarna agama. Menggugat penggunaan kata dalam hal seperti ini tidak akan menemui ujungnya kecuali memisahkan kedua hal dalam masing-masing istilah yang berbeda atau dengan memberikan kata penjelas untuk membedakannya. Sedang fakta keberagamaan plural bangsa merupakan potensi tinggi untuk memajukan masyarakatnya, karena meski agama berbeda secara nilai kebenaran bagi masing-masing pemeluknya tetapi dalam tataran praktik sosial kemanusiaan semua agama tidak bertentangan dengan nilai kebenaran universal.

Keberagaman majemuk bangsa seluas Indonesia rentan dan berpotensi perpecahan. Dan dia dalam waktu yang sama merupakan anugerah yang harus dirawat dan dijaga. Menjaga keberanekaragaman berarti menjaganya agar tetap menjadi harmoni bukan agar selalu bertambah kuantitas ragamnya. Karena prestasi bangsa terletak pada keberhasilannya merawat keberagamannya untuk tetap indah, sehat dan produktif, bukan pada bermunculannya jenis-jenis perbedaan tanpa batas dan penuh friksi. Menjaga keberagaman bangsa memerlukan pemerintahan yang kuat, dapat jeli melihat dan memastikan agar semua elemen perbedaan mendapatkan haknya secara proporsional, aman dan tanpa gesekan dengan berpegang pada asas keadilan. Pemerintahan yang cerdas akan melihat potensi keragaman agama yang dapat dimaksimalkan membangun mental manusia-manusia negeri ini. Yang pada akhirnya akan bermanifestasi peradaban yang produktif dan maju. Untuk itu kewajiban pemerintah untuk mendorong setiap individu untuk menjadi hamba Tuhan-nya yang bermoral dan shalih, agar asas pemersatu bangsa berupa Pancasila tidak sia-sia dirumuskan. Wallahu a'lam bis shawaab.

\section{REFERENSI:}

Abdalla, Ulil Abshar, Pluralisme dan Pluralitas: Dua Sisi Dari Koin Yang Sama, https://islamlib.com/topik/pluralisme/, diakses tanggal 20 Maret 2020. 
Abduh, Muhammad, Tafsir Al Qur'an al Karim Juz Amma, Kairo: Dar wa Matabi' al Sya'b, t.t

Al Bukhari, Muhammad Ibnu Isma'il, al-Jami'al-Musnad as-Shahih Min Umuri Rasulillahi shallallahu 'alaihi wasallam Wa Sunanihi Wa Ayyamihi, atau Shahih Al-Bukhari, Beirut: Dar Ibni Katsir, 2002, jilid. 6, hal. 37, No. 4556, bab Qul Fa'tu bi at-Taurati fatluha in kuntum shadiqin (Q.S Ali 'Imran:3/93)

Arif, Syamsuddin," Interfaith Dialogue" dan Hubungan Antaragama dalam Perspektif Islam", Jurnal Tsaqafah, Vol. 6, No I, April 2010, hal: 158.

https://id.m.wikipedia.org/wiki/Imagine, diakses tanggal 15 Maret 2020

https://kbbi.web.id/radikal, diakses tanggal 20 Maret 2020.

https://republika.co.id/berita/n91u2942/menjaga-hak-dan-kewajiban, diakses tanggal 20 Maret 2020

https://republika.co.id/berita/ps0674313/sistem-millet-mulai-berlaku-di-masa-usman-i, diakses tanggal 20 Maret 2020

Ma'arif, Ahmad Syafi'i, Menimbang Kembali Keindonesiaan Dalam Kaitannya Dengan Masalah Keadilan, Kemanusiaan, Kebhinnekaan Dan Toleransi, Fiqih Kebhinnekaan, Bandung: Mizan, 2014.

Madjid, Nurcholish, Atas Nama Pengalaman Beragama dan Berbangsa di Masa Transisi, Kumpulan Dialog Jum'at di Paramadina, Jakarta: Paramadina 2002

Madjid, Nurcholish, Indonesia Kita, Jakarta: Gramedia Pustaka Utama, 2003.

Moko, Catur Widiat, Pluralisme Agama Menurut Nurcholis Madjid (1939-2005) dalam Konteks Keindonesiaan, Medina-Te, Vol. 16, No. 1, Juni 2017.

Muttaqien, Ahmad, Rekonstruksi Gagasan Pluralisme Agama, Jurnal Al-Adyan, Vol. IX, No. 1/ Januari-Juni/2014.

Muzadi, Hasyim: Mau Aman, Ahmadiyah Agama Baru, https://m.hidayatullah.com/berita/nasional/read/2011/02/23/46652/hasyimmuzadi-mau-aman-ahmadiyah-agama-baru.html, diakses: 20 Maret 2020.

Muzani, Saiful, Mitos Politik dan Aspirasi Politik ICMI Modernis, Book Review, Adam Schwarz, "Islam: Coming in from the cold?, dalam bukunya, A Nation in Waiting, Indonesia in the 1990's, (Sydney: Allan and Urwin, 1994) , Studia Islamika, Vol. 2, No. 1, 1995

Rachman, Budhy Munawwar, Perspektif Global Islam dan Pluralisme, Ilmu Ushuluddin, Vol. 1, No. 3, Januari 2012

Rakhmat, Jalaluddin, Islam dan Pluralisme, Akhlak Qur'an menyikapi Perbedaan, Jakarta: Serambi, 2006

Ridha, Muhammad Rasyid ,Tafsir Al-Qur'an Al Hakim, Beirut: Dar al Fikr, 1973

Rifai, Muhammad, Gus Dur, Jogjakarta:Ar-Ruzz Media, 2013.

Thoha, Anis Malik, Pluralisme Agama sama dengan Agama Baru, wawancara Henri Shalahuddin, Jurnal Islamia, Hermeneutika versus Tafsir Al-Qur'an, th. I, No. 1, Muharram 1425.

Wahid, Abdurrahman, Islamku Islam Anda Islam Kita, Jakarta: Wahid Institute, 2006.

Wahid, Abdurrahman, Bercermin Dari Para Pemimpin, dalam Abdul Mun'im D.Z. (ed), Islam di Tengah Arus Transisi, Jakarta: Kompas, 2000.

Wahid, Abdurrahman, Prisma Pemikiran Gus Dur, Yogyakarta: LKiS, 2010. 